\title{
Landslide susceptibility zonation in part of Tehri reservoir region using frequency ratio, fuzzy logic and GIS
}

\author{
Rohan KumaR* and R Anbalagan \\ Department of Earth Sciences, Indian Institute of Technology, Roorkee, Uttarakhand, India. \\ ${ }^{*}$ Corresponding author. e-mail: rohananandi@yahoo.com
}

A comprehensive study for the identification of landslide susceptible zones using landslide frequency ratio and fuzzy logic in GIS environment is presented for Tehri reservoir rim region (Uttarakhand, India). Temporal remote sensing data was used to prepare important landslide causative factor layers and landslide inventory. Primary and secondary topographic attributes namely slope, aspect, relative relief, profile curvature, topographic wetness index, and stream power index, were derived from digital elevation model. Landslide frequency ratio technique was adopted to correlate factors with landslides. Further, fuzzy logic method was applied for the integration of factors (causative factor) to map landslide susceptible zones. Normalized landslide frequency ratio value was used for the fuzzy membership function and different fuzzy operators were considered for the preparation of landslide susceptibility/hazard index map. The factors considered in this study were found to be carrying a wide range of information. Accordingly, a methodology was evolved to integrate the factors using combined fuzzy gamma and fuzzy OR operation. Fuzzy gamma integration was performed for six different gamma values (range: 0-1). Gamma value of 0.95 was selected for the preparation of final susceptibility map. Landslide susceptibility index map was divided into the following five hazard zones - very low, low, moderate, high, and very high on the basis of natural break classification. Validation of the model was performed by using cumulative percentage curve technique. Area under curve value of cumulative percentage curve of proposed landslide susceptibility map (gamma $=0.95$ ) was found to be 0.834 and it can be said that $83.4 \%$ accuracy was achieved by applying combined fuzzy logic and landslide frequency ratio method.

\section{Introduction}

Landslide is the result of a wide variety of geoenvironmental processes which involve geological, meteorological and human factors. The main factors which influence landsliding were discussed by Varnes (1984) and Hutchinson (1995). Most important inherent factors are bedrock geology (lithology, structure, degree of weathering), geomorphology (slope gradient, aspect, and relative relief), soil (depth, structure, permeability, and porosity), land use/land cover, and hydrologic conditions. Landslides are triggered by many extrinsic causative factors such as rainfall, earthquake, blasting and drilling, cloudburst, and flashfloods.

Tehri reservoir (67 km long) was developed due to the construction of a $260.5 \mathrm{~m}$ high dam across the confluence of Bhagirathi and Bhilangana rivers on the highly rugged Lesser Himalayan terrain. Several studies have indicated that impoundment of the reservoir has induced negative impacts on the surrounding geoenvironmental system (AHEC 2008). A number of villages are situated all around the rim of the reservoir. Due to readjustment of slopes during drawdown conditions of the reservoir, the slopes on which villages are located have

Keywords. Fuzzy logic; landslide susceptibility; frequency ratio.

J. Earth Syst. Sci. 124, No. 2, March 2015, pp. 431-448

(C) Indian Academy of Sciences 
been rendered unstable in many areas in addition to loss of huge areas of farm land. Geoenvironmental factors such as slope, relative relief, hydrogeological condition, lithology, and structural discontinuity are responsible for the slope instability in the reservoir rim region. Characterization of landslide causative factors and a comprehensive landslide probability mapping are the most important planning strategies for mitigation. Identification of the landslide probable zones are based on the assumption that landslides in the future will be more likely to occur under those conditions which led to the past and present instability (Varnes 1984; Carrara et al. 1995; Guzzetti et al. 1999; Kanungo et al. 2006). 'Landslide susceptibility zonation' (LSZ) term adheres to principles of landslide hazard zonation (LHZ) and landslide susceptibility mapping (LSM). For landslide study, Varnes (1984) defined zonation as division of the land surface into areas and ranking these areas according to the degree of actual or potential hazard from landslides or other mass movement on the slopes. On the other hand, Brabb (1984) introduced the term 'landslide susceptibility', which is the spatial probability of occurrence of landslide based on a set of geoenvironmental factors. Both terminologies have been extensively used in landslide hazard study (Anbalagan 1992; Pachauri and Pant 1992; Nagarajan et al. 1998; Gupta et al. 1999; Saha et al. 2002; Lee et al. 2002, 2005; Arora et al. 2004; Sarkar and Kanungo 2004; Ayalew and Yamagishi 2005; Akgun et al. 2008; Yilmaz 2009; Das et al. 2010; Hasekioğullari and Ercanoğlu 2012; Kayastha et al. 2013a, b; Kumar and Anbalagan 2013). A vast group of authors have been using the term 'landslide hazard mapping' in which they follow the definition of natural hazard given by Varnes (1984) and accordingly probability of occurrence of a landslide within a given time is considered. Time factors related to events such as rainfall, earthquake or temperature variation are incorporated as input parameters to predict landslide hazard (Guzzetti et al. 1999, 2005; Van Westen et al. 2003; Ghosh et al. 2009). Since absolute time factors are difficult to predict, they are often incorporated hypothetically rather than based on active ground data. Hence, in the present study LSZ, LSM and LHZ are considered to convey the same meaning.

Remote sensing provides effective means to map landslides in a highly inaccessible terrain. Temporal capability of remote sensing data offers coverage of a landslide-prone area prior to rainfall and after rainfall. Remote sensing has also proven its capability in the mapping of landslide causative factors. GIS provides a platform for the spatial data extraction, analysis and integration. Remote sensing and GIS have been extensively used in landslide susceptibility studies. For LSZ mapping, weighing/ratings of factors and their attributes are most important prerequisites. Data integration of landslide causative factors is an indispensible requirement for the LSZ mapping. A number of qualitative and quantitative weighting/rating and data integration techniques have been in practice for the LSZ in GIS environment. It can be broadly classified into the following three groups - heuristic/qualitative, semi quantitative and quantitative/statistical methods. Heuristic methods assume subjective knowledge of professionals to weight factors affecting landslide (Saha et al. 2002; Sarkar and Kanungo 2004). Quantitative methods consider correlation of landslide inventory with concerned factors. These are data-driven methods which require a comprehensive landslide inventory and can further be divided into bivariate and multivariate statistical categories. Bivariate statistical method assumes landslide as the dependent variable and causative factors as independent variables. Association of each factor with the landslides is individually computed on the basis of landslide density (Lee et al. 2002; Saha et al. 2005; Dahal et al. 2008; Mathew et al. 2009; Ghosh et al. 2009; Pradhan et al. 2010; Kayastha et al. 2012). In the multivariate approach, combined impact of factors on the dependent variable is computed and, at the same time, weights of individual factor can also be derived (Ayalew and Yamagishi 2005; Lee 2005; Guzzetti et al. 2005; Yilmaz 2009; Das et al. 2010, 2012; Pradhan et al. 2010; Kundu et al. 2013). Another quantitative technique, deterministic model is based on the slope geometry, geological discontinuity and other geotechnical properties of the rocks. It gives results in terms of factor of safety (Sharma et al. 1994; Chakraborty and Anbalagan 2008; Singh et al. 2008). Semi-quantitative methods are based on weighing and rating such as AHP (analytical hierarchy process) approach, fuzzy logic approach, combined landslide frequency ratio and fuzzy logic and weighted linear combination (WLC) (Ercanoglu and Gokceoglu 2004; Kanungo et al. 2006; Champatiray et al. 2007; Ercanoglu et al. 2008; Yalcin 2008; Pradhan et al. 2009; Mondal and Maiti 2012; Kayastha et al. 2013a, b).

Different researchers attempted to evolve techniques on LSZ by using different methods in the Himalayan region. Sharma et al. (1994), Anbalagan et al. (2008) and Singh et al. (2008) used deterministic approach by considering geotechnical parameters on local scale. Anbalagan (1992) used slope facet as a terrain unit and landslide hazard evaluation factor (LHEF) as ratings criteria to evolve hazard zones. GIS based subjective approach was carried out by Gupta et al. (1999), Saha et al. (2002), and Sarkar and Kanungo (2004) in different parts of the Himalayan terrain. Arora et al. (2004) introduced artificial neural network method for LHZ mapping in the Ganga valley of the Himalayas. Spatial data 
analysis for landslide hazard was carried out by Sarkar et al. (2008). Mathew et al. (2007) used weights of evidence technique to assign weights to different landslide causative factors. Empirical modelling for landslide susceptibility in Darjeeling Himalaya was attempted by Gosh et al. (2011). Das et al. (2010) had applied multivariate logistic regression technique to identify landslide hazard zones in Indian Himalayas. Fuzzy logic approach was applied in Himalayan terrain by Kanungo et al. (2006), Champatiray et al. (2007) and Kayastha et al. (2013a, b).

Literature review of LSZ practices in the Himalayan region has reflected that less importance was given to the feasibility of the factors used in susceptibility model. Apart from the inherent landslide causative factors, a number of topographic indices were used for LSZ mapping; whereas, use of secondary topographic indices such as topographic wetness index (TWI) and stream power index (SPI) were found to be lacking. The secondary topographic indices are important factors, because they give an idea about the role of topography in the distribution of vegetation, water, mass movement, and solar radiation (Wilson 2011). Characterization of reservoir induced terrain changes was found to be another important scope of study. Few authors applied fuzzy logic approach for LSZ in Himalayan terrain. Optimum use of different fuzzy operators for factors representing a wide variety of information and suitability of fuzzy logic method in present terrain condition are presented in this study.

\section{Study area}

A $260.5 \mathrm{~m}$ high Tehri dam, which became operational in the first decade of this century is one of the biggest dams of the world. It is located in Garhwal Himalaya in the Lesser Himalayan terrain $\left(30^{\circ} 22^{\prime} 40^{\prime \prime} \mathrm{N} / 78^{\circ} 28^{\prime} 50.4^{\prime \prime} \mathrm{E}\right)$. The construction of the dam has resulted in the formation of a huge reservoir $(67 \mathrm{~km})$ in Bhagirathi and Bhilangana valley. Maximum reservoir level (MRL) is $830 \mathrm{~m}$ and dead storage level (DSL) is $740 \mathrm{~m}$. The reservoir water fluctuates between MRL and DSL during the draw down condition. When the reservoir is at maximum level, it saturates the valley slopes. When the water level goes down, it considerably saturates side slopes, which often become unstable and may create slope instability problem in a number of places. The instability problem varies from place to place depending on: (a) type of slope material, (b) geometry of rock slope, (c) vegetation cover, and (d) human interference within the reservoir rim boundary. The drawdown condition of the reservoir has a distinctly adverse impact on the stability of the reservoir rim area, which is manifested in the form of landslides. Reservoir rim area characterized by rocks does not show instability problem in general. The landslide which is caused within the loose unconsolidated material has affected civil structures located within the area: namely houses, school, government offices, and other such structures. Figure 1 refers to the study area.

\subsection{Geological setting}

Several geological studies have been carried out in the present study area. The most prominent study was carried out by Valdiya (1980). The whole study area is a part of the broader physiographic entity called Lesser Himalaya and comprised of inner as well as outer Lesser Himalaya. The rocks exposed in the study area belong to the inner as well as the outer Lesser Himalaya. The inner Lesser Himalaya, in the study area is represented by the rocks of Rautgara Formation of Damtha Group, Deoban and Mandhali Formation of Tejam Group, and Berinag Formation of Jaunsar Group. On the other hand, the rocks exposed in the outer Lesser Himalaya belong to the Chandpur and Nagthat Formation of Jaunsar Group and Blaini Formation of Mussoorie Group. The stratigraphic succession of the study area is shown in table 1 and the distribution of different formations belonging to the various groups is shown in figure 2 . The central part of the area is represented by Chandpur Formation. Rocks of Chandpur Formation are low grade metamorphosed lustrous phyllites and highly weathered quartzites. Nagthat rock formation is found in the western part of the study area. Rocks of Nagthat Formation are characterized by white, purple, and green coloured quartzites with subordinate intercalation of grey and olive green slates with siltstones. In the eastern part of the study area, North Almora Thrust (NAT) separates Jaunsar Group of rocks from Damtha Group (Rautgara Formation). Rocks of Rautgara Formation comprise purple, pink, and white coloured, well jointed, medium grained quartzites, minor slates and metavolcanics. Deoban Formation is found in eastern and northeastern parts of the study area. It is sandwiched between Rautgara Formation and Berinag Formation in the south. Deoban Formation consists of fine grained dolomitic limestone with minor phyllitic intercalations. These rocks are mainly found at the higher ridges. Rocks of Berinag Formations are exposed in the eastern part of the area. It is separated by Berinag thrust at its base. These rocks are mostly quartzites. Bliani Formations are found in the western part of the study area. This formation comprises quartzites, slates and carbonate rocks. 


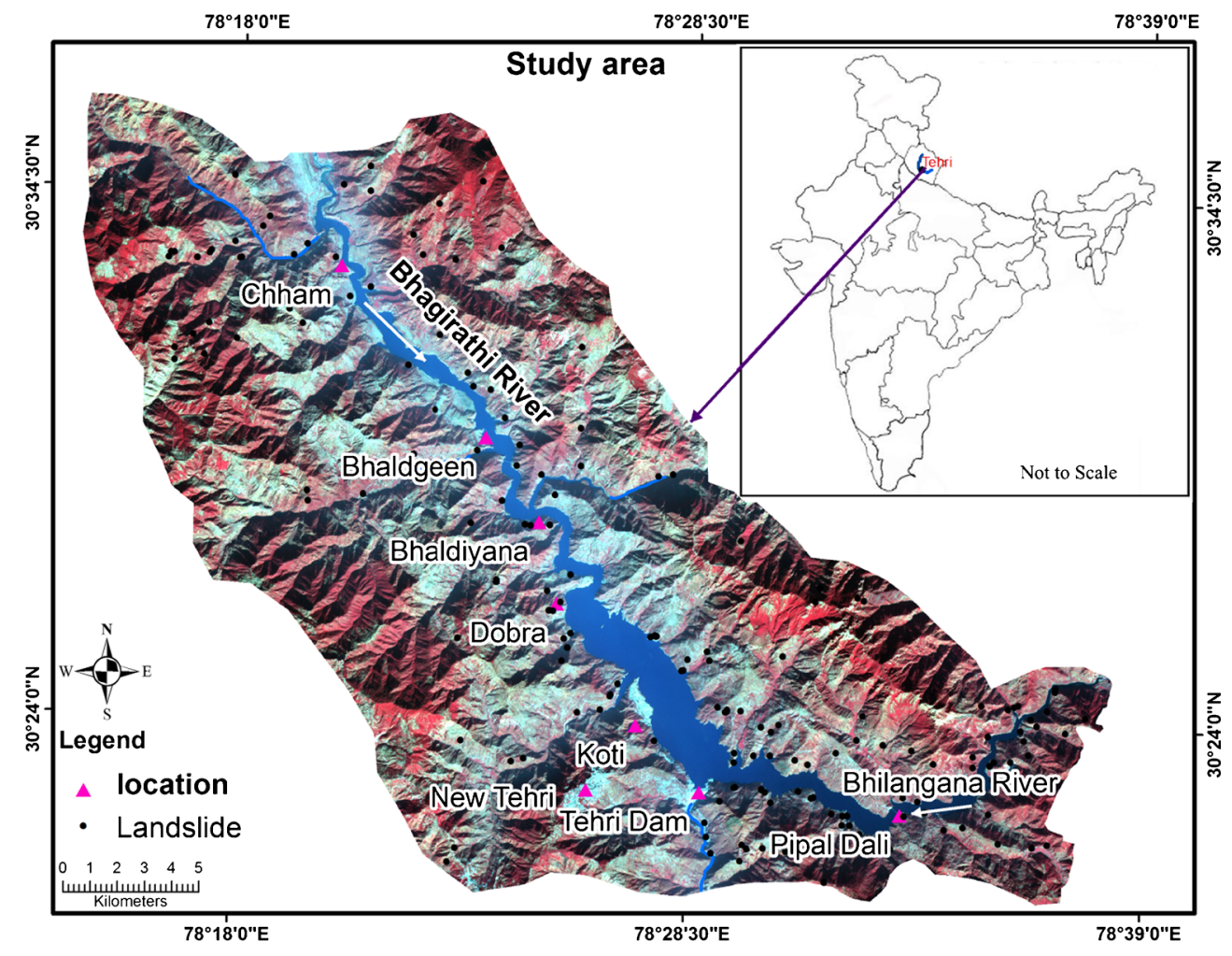

Figure 1. Study area.

Table 1. Stratigraphic succession of the study area.

\begin{tabular}{|c|c|c|c|c|}
\hline \multirow{3}{*}{$\frac{\text { Group }}{\text { Mussoorie }}$} & \multicolumn{2}{|c|}{ Inner Lesser Himalaya } & Outer Lesser Age Himalaya & \multirow[b]{2}{*}{ Rock type } \\
\hline & \multicolumn{3}{|c|}{ Formations } & \\
\hline & & Blaini & Neoproterozoic & $\begin{array}{l}\text { Quartzite, limestone, slates, phyllites } \\
\text { and conglomerate }\end{array}$ \\
\hline \multirow[t]{2}{*}{ Jaunsar } & Berinag & Nagthat & Mesoproterozoic & $\begin{array}{l}\text { Weathered quartzite intercalated } \\
\text { with slate }\end{array}$ \\
\hline & & Chandpur & Mesoproterozoic & Low grade lustrous phyllites \\
\hline Tejam & Deoban & Mandhali & Mesoproterozoic & $\begin{array}{l}\text { Dolomitic limestone with phyllitic } \\
\text { intercalations }\end{array}$ \\
\hline Damtha & Rautgara & & $\begin{array}{l}\text { Mesoproterozoic } \\
(>1300 \mathrm{my})\end{array}$ & Quartzite, slate, metavolcanic rocks \\
\hline
\end{tabular}

Major as well as minor structures have been observed in the study area. The major structural features include the NAT, exposed in the northeastern region. The south-easterly dipping NAT separates the Chandpur phyllites from the Rautgara Formation towards north (figure 2). A number of antiforms and synforms in the central and south-western regions, which together form a part of the Mussoorie syncline (Valdiya 1980) have been observed. A number of shear zones of varying shapes and sizes were observed during the field work.

\section{Data preparation}

Raw remote sensing (ASTER) multispectral data was processed with ENVI 4.5 software. Different bands were extracted and georeferenced to UTM WGS 1984 Zone 44. VNIR (Visible Near Infrared) bands were selected for the factor extraction. Topo-normalization was performed on the basis of ASTER DEM (Digital Elevation Model). ASTER DEM and Cartosat-1 DEM data were subjected to DEM enhancement techniques such as DEM fill and sink removal. Ancillary data such as landslide inventory, geological map, soil map, and topographic map were acquired from different sources. Processing of ancillary data involved rasterization according to the unit grid size of $25 \mathrm{~m} \times 25 \mathrm{~m}$. Co-registration of the remote sensing and ancillary data were carried out to prepare a base map of the study area. According to the base map, 13 factor maps were prepared in raster grid form. Remote sensing data were used to acquire landslide 


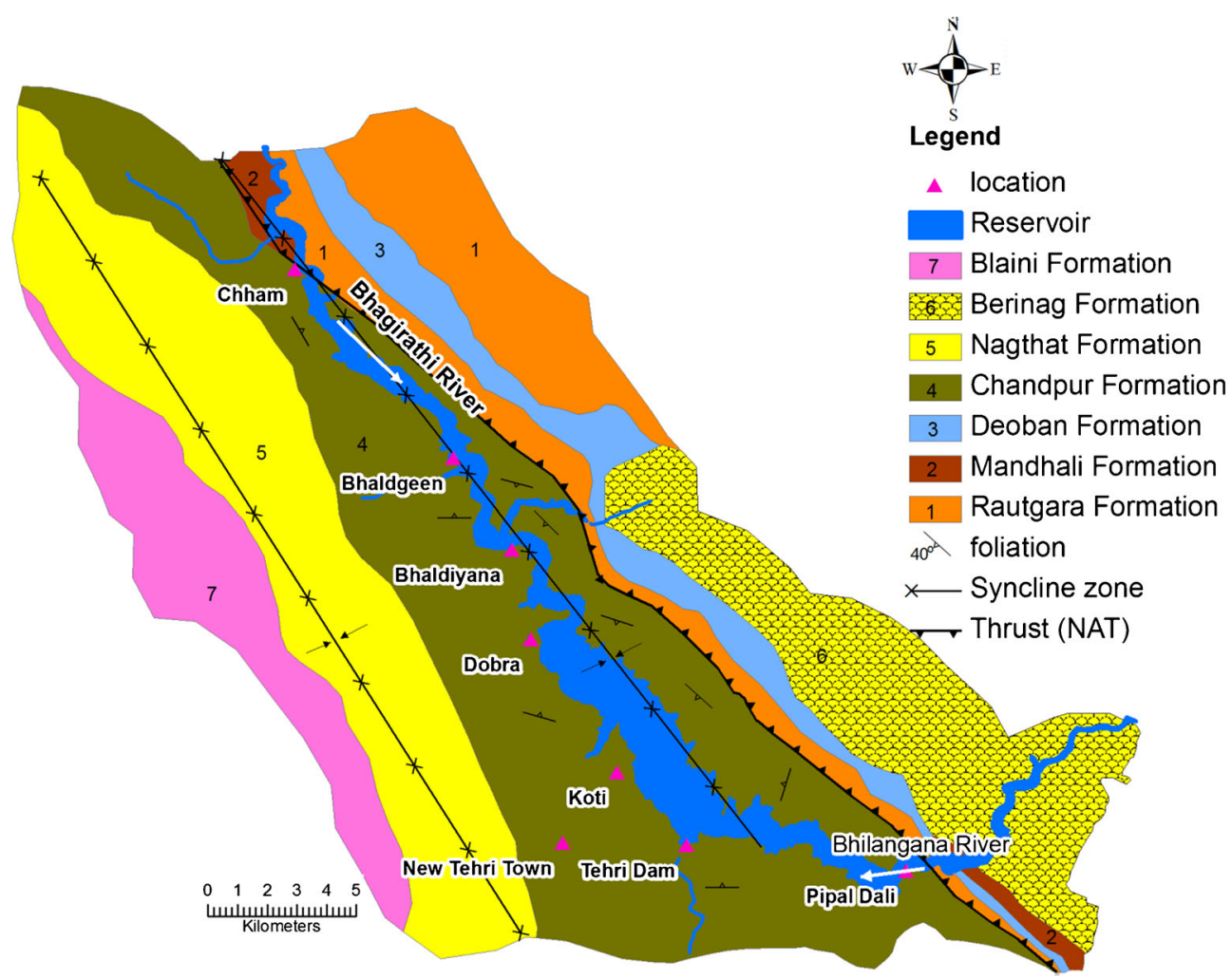

Figure 2. Geological map of the Tehri reservoir rim area (after Valdiya 1980).

Table 2. Data used in the present study.

\begin{tabular}{llll}
\hline Data type & \multicolumn{1}{c}{ Sensor } & Scale & \multicolumn{1}{c}{ Data derivative } \\
\hline Image data & ASTER & $15 \mathrm{~m} \times 15 \mathrm{~m}$ grid & LULC \\
& Porld view - & $0.5 \mathrm{~m} \times 0.5 \mathrm{~m}$ grid & Photo-lineament \\
Cartosat 1 & $2.5 \mathrm{~m} \times 2.5 \mathrm{~m}$ grid & Slope \\
ASTER GDEM & $15 \mathrm{~m} \times 15 \mathrm{~m}$ grid & Aspect \\
& & Relative Relief \\
& & Profile curvature \\
& & TWI \\
& & SPI \\
& & Drainage \\
& & Vector geology map \\
& & Vector soil map \\
& & $1: 250000$ & Vector topographic map \\
& $1: 250000$ & Vector landslide inventory \\
\hline
\end{tabular}

inventory, land use/land cover (LULC), and photolineament by applying digital image processing techniques such as NDVI, supervised classification, band rationing, etc. Onscreen visualization based on colour, tone, texture, pattern, shape, and shadow were performed for the identification of the landslide inventory. DEM was used for the extraction of topographic attributes namely slope, aspect, relative relief, profile curvature, topographic wetness index, and stream power index. Drainage map was also generated from the DEM. Table 2 shows data used in the present study.

\subsection{Lithology}

Lithological map of the area was prepared based on the study of Valdiya (1980) and field studies (figure 2). Seven different geological formations belonging to four different groups are represented in the study area. Rocks of Chandpur Formation are low grade metamorphosed lustrous phyllites and highly weathered quartzites. These rocks are highly vulnerable to sliding because of the presence of well developed foliation plains and joints. Nagthat Formation is found in the western part of the study area. Rocks of Nagthat Formation are 
characterized by white, purple, and green coloured quartzites with subordinate intercalation of grey and olive green slates with siltstones. Different patterns of weathering was observed in quartzites belonging to Nagthat Formation. Shearing was found to be the common discontinuity in those rocks. Rocks of Rautgara. Formation comprise purple, pink, and white coloured, well jointed, medium grained quartzites, minor slates, and metavolcanics. Deoban Formation is found in eastern and north-eastern parts of the study area. It is sandwiched between Rautgara Formation and Berinag Formation in the southern part of the study area. Deoban Formation consists of fine grained dolomitic limestone with minor phyllitic intercalations. These rocks are mainly found at the higher ridges. Rocks of Berinag Formation are exposed in the eastern part of the area. It is separated by Berinag thrust at its base. These rocks are mostly quartzites. Bliani Formations are found in the western part of the study area. This formation comprises quartzites, slates, and carbonate rocks. No substantial landslides are observed in rocks of Mandhali Formation.

\subsection{Land use/land cover ( $L U L C$ )}

LULC pattern of the terrain has a huge influence on landslide susceptibility study. Five categories of LULC namely dense forest, open/scrub forest, agricultural land, settlement/barren land and water body were derived from the combination of topographic map and satellite imageries (figure 3). LULC maps were prepared from ASTER multispectral data of $15 \mathrm{~m}$ spatial resolution by performing NDVI (Normalized Difference Vegetation Index) and supervised classification. Vegetation thresholds were obtained from NDVI and other classes from supervised classification. Reasonable accuracy (78\%) was achieved for LULC mapping.

\subsubsection{Soil cover}

Soils of the area consist of alluvial, sandy loam, skeletal, forest soil and red soil. Soil quality varies with the relief/elevation and annual rainfall. Elevation varies roughly from 500 to $2600 \mathrm{~m}$. Rainfall varies according to the aspect of slope faces (source - published report of Watershed Management Directorate, Dehradun). At lower elevations (600-1000 m), mainly alluvial mixed with boulders are present. In 1000-1500 $\mathrm{m}$ range, sandy loamy soils are present. Above $1500 \mathrm{~m}$, red/black forest soils are present. Each category of soil has analogous influence on landslides. Forest soil is relatively less prone to weathering. Alluvial and loose boulders are highly prone to mass movement. Sandy loamy soil is also weathering prone.

\subsubsection{Structure and photo-lineament analysis}

The area falls under Lesser Himalayan terrain. A number of geological discontinuities like faults, thrusts, folds and joints of varying shape and size

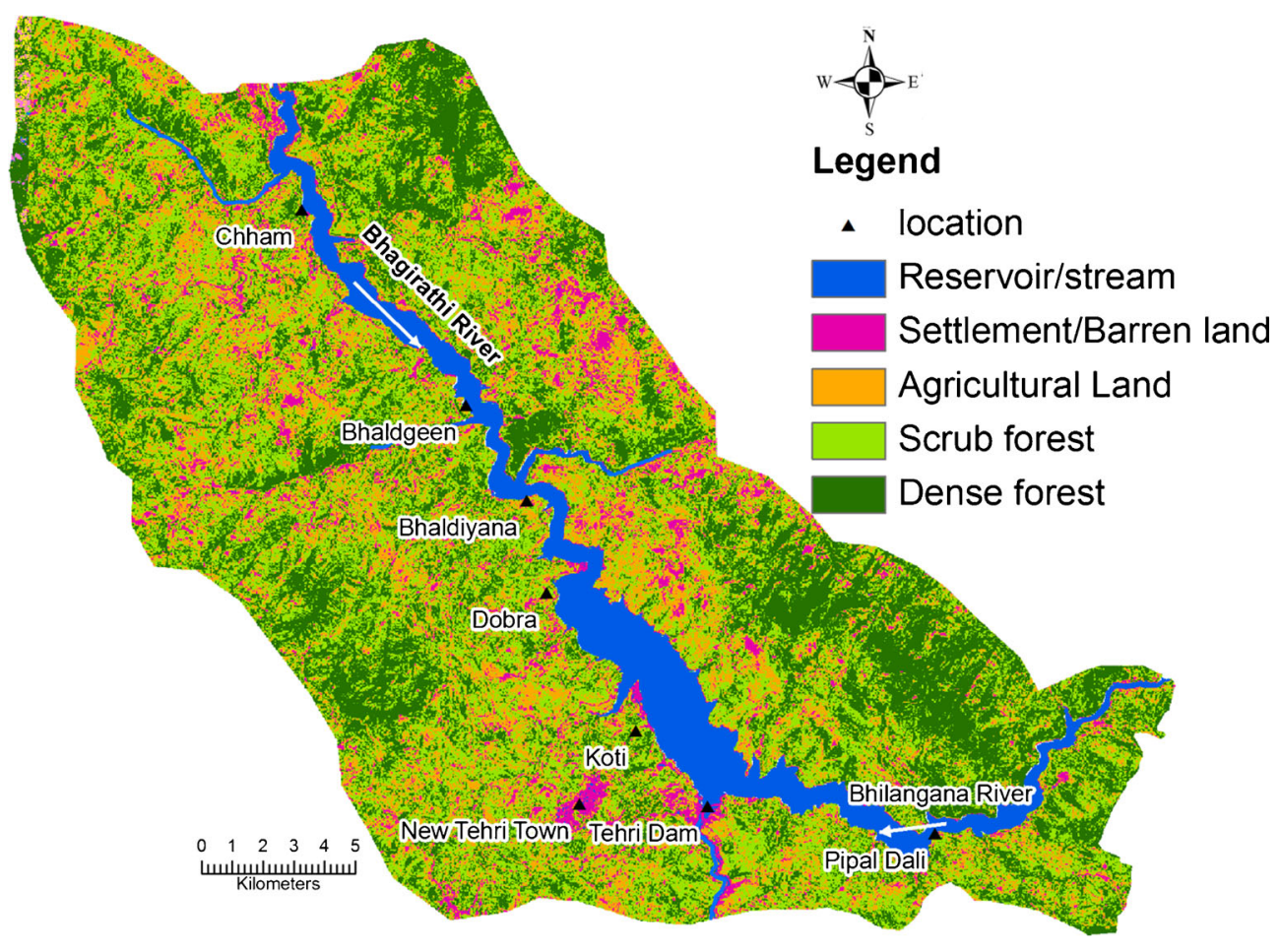

Figure 3. LULC map of the Tehri region. 
can be seen in large numbers in the area. Two major synclines and North Almora Thrust (NAT) are the major regional structural features present in the area (figure 2). Minor to major depressions are seen along the axial zone of synclines in the area. NAT crosses through eastern and north eastern sides of the area, crossing the reservoir at Chham where it forms visible scrap faces on the left bank adjoining the river course. Moreover, since the trend of NAT is nearly parallel to the river course (now reservoir), where it crosses the reservoir, the scrap face extends over a long distance. Linear geological discontinuities can be delineated from multispectral image and DEM, accordingly a photo-lineament map of the area was prepared. Landslides are associated with the proximity to lineament (Gupta et al. 1999). A distance to lineament map (also called lineament buffer map) covering 50, 100, 150 and $200 \mathrm{~m}$ distances was prepared complying with field evidences of landslides. More landslides were observed in areas closer to the photo-lineaments.

\subsubsection{DEM derivatives}

Primary topographic attributes, such as slope, aspect, relative relief, and curvature, were derived from DEM data. Secondary topographic attributes can be computed from two or more primary attributes, and are important because it gives an idea about the role of topography in distribution of water and solar radiation which further has great importance in vegetation and mass movement process (Wilson 2011).

\subsubsection{Primary topographic attributes}

Topographic slope, aspect, relative relief, and curvature were derived from DEM by using Arc GIS 9.3 software. Slope was in the range of $0^{\circ}-70^{\circ}$. Slope was divided into five classes according to its inherent influence on the landslide. It has been widely perceived that area with higher slope gradient is more prone to landslides, whereas area having low slope gradient is less prone (Anbalagan 1992; Gupta et al. 1999; Saha et al. 2005; Kayastha et al. 2013a, b). Five slope categories namely very low $\left(0^{\circ}-8^{\circ}\right)$, low $\left(8^{\circ}-18^{\circ}\right)$, moderate $\left(18^{\circ}-30^{\circ}\right)$, high $\left(30^{\circ}-42^{\circ}\right)$, and very high $\left(>42^{\circ}\right)$ were categorised from the ordered data. Topographic aspect influences landslide probability. Aspect of a slope face determines concentration of sun rays, which is associated with temperature and related climatic condition. In the Himalayan region, influence of aspect on the terrain can be seen, with south-facing slopes being warm, wet and forested, whereas north-facing slopes are cold, dry and glaciated. Southfacing slopes of Himalayan terrain are more susceptible to landslides. In the present study, aspect was divided into 10 classes. Another important DEM derivative is relative relief which is the difference between maximum and minimum elevation point within a facet or area (Gupta et al. 1999). In the present study, relative relief was found to be varying between 0 and $367 \mathrm{~m}$. Following five classes of relative relief: very low relief $(0-$ $30 \mathrm{~m})$, low relief $(30-60 \mathrm{~m})$, moderate relief $(60-$ $100 \mathrm{~m})$, high relief $(100-150 \mathrm{~m})$, and very high relief $(>150 \mathrm{~m})$ were considered for the LSZ. Field observations have suggested that terrains having high relative relief are more prone to landslide compared to low relative relief. Together with the other factors, slope curvatures control the flow of water in and out of slopes and are, therefore, important in the study of landslides (Ayalew and Yamagishi 2005). Profile curvature was considered for this study. Profile curvature is computed parallel to the direction of the maximum slope in which, a negative value indicates that the surface is upwardly convex at that cell; a positive profile indicates that the surface is upwardly concave at that cell and a value of zero indicates that the surface is linear (ESRI 2012). Profile curvature affects the acceleration or deceleration of flow across the surface and it may be associated with mass movement/erosion processes. Accordingly a profile curvature map was prepared, showing concave and convex profiles.

\subsubsection{Secondary topographic attributes}

Topographic wetness index (TWI) and stream power index (SPI) were the two secondary topographic units considered for the landslide susceptibility study. TWI considers catchment area and slope gradient (Wilson 2011). It can be calculated from the following formula:

$$
\mathrm{TWI}=\ln \frac{C A}{\tan s l p}
$$

where $C A$ stands for catchment area and $s l p$ for slope gradient of the area. TWI is associated with flow accumulation at the given terrain. It is effectively used to understand the soil moisture condition and other related phenomenon. With the increase of catchment area and decrease of slope gradient, soil moisture content and TWI of a terrain increases. Flow accumulation in a terrain is controlled by TWI. Other parameters such as distribution of water saturation zones, water table, evapotranspiration, silt and sand content, and vegetation are associated with TWI. In a reservoir rim environment, fluctuation of reservoir water between MRL and FRL induces water saturation in side slopes, which reduces its stability. 
Determination of TWI is helpful in delineating saturation zone and water table conditions. TWI value (on log scale) was found to vary in a range of 5-19, which was further classified into four classes as referred in the figure 4(a).

SPI also takes into account catchment area and slope gradient. It shows the erosive power of the stream. It can be calculated by using the following formula:

$$
\mathrm{SPI}=\ln (C A \times \tan s l p)
$$

SPI is directly proportional to catchment area and slope gradient. Increase in catchment area and slope gradient increases the erosion potential of a stream. The Tehri reservoir rim area has very high stream density, which triggers a number of landslides during monsoon season. SPI resulted in the erosive power of the streams of the area. SPI was found to range between 1.5 and 15. Higher values are associated with number of landslides. SPI values were categorized into five types (figure 4b) by applying natural break classifier (ESRI 2012).

\subsection{Buffer layers}

Apart from lineament, reservoir, road and drainage buffer maps were prepared in view of proximity of landslides. Reservoir water fluctuation (up to $50 \mathrm{~m}$ ), saturates side slopes (banks), which causes landslides. A number of landslides are reported from the adjoining areas also. Field observations suggest frequency of landslide along the reservoir rim region (figure 5), accordingly reservoir multibuffer map (100, 200, 300, 400 and $500 \mathrm{~m}$ ) was prepared. Very high number of landslides was observed along the roads which were constructed by cutting the slopes randomly. Cut slopes along the road network were found to be standing steeply and

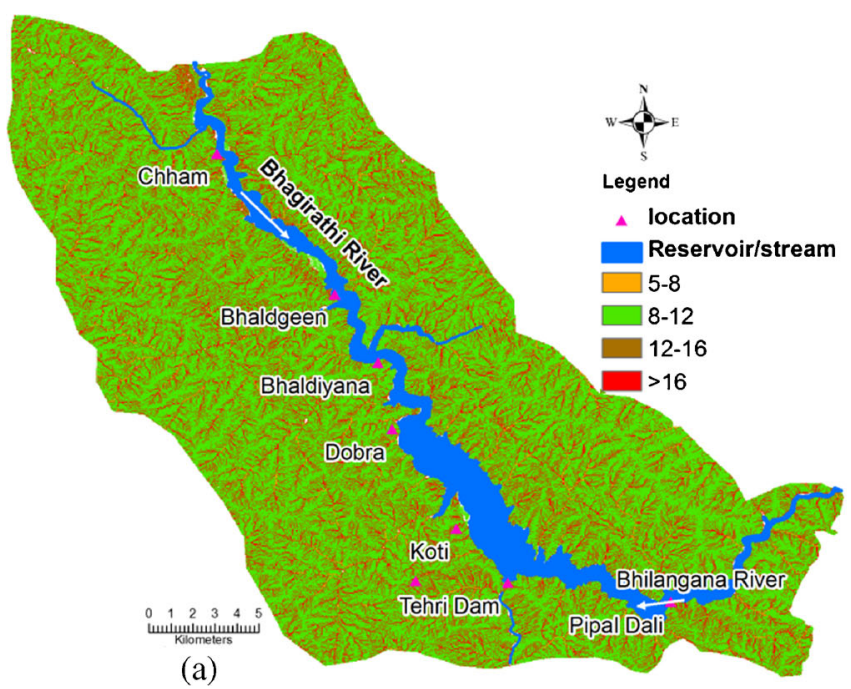

sometimes overhanging. Most of the cut slopes observed were kept untreated. During monsoon, these cut slopes fail frequently and obstruct transportation. Most of the failed slopes are progressive in nature as observed in the field. Road multibuffer $(50,100,200 \mathrm{~m})$ layer was prepared in view of landslide proximity to roads.

\subsection{Drainage}

Drainage map was derived from ASTER DEM in Archydro tool of ESRI GIS package. High drainage density was observed from DEM analysis with up to 5 th order stream present. Highly undulating terrain of the area supports a number of small drainages. Drainage network has compelling relation with the landslides. In hilly regions, streams continuously erode its banks and create steep side slopes, which are highly prone to failures. A number of such failures were observed during field investigation. These failures are also progressive in nature. More landslides were observed closer to streams. For assessment of landslide susceptibility, drainage buffer maps (50, 100, 150 and $200 \mathrm{~m}$ ) were prepared complying with field evidences.

\section{Fuzzy modelling}

Fuzzy set theory was introduced by Zadeh (1965). It facilitates analysis of non-discrete natural processes as mathematical formulae (Zimmermann 1996). According to this theory, membership value of elements $(x)$ has varying degrees of support and confidence $(f(x))$ in the range $(0,1)$ (Ercanoglu and Gokceoglu 2002). A fuzzy set can be described by the below formula as:

$$
A=\left\{x, f_{A}(x)\right\}, \quad x \in R .
$$

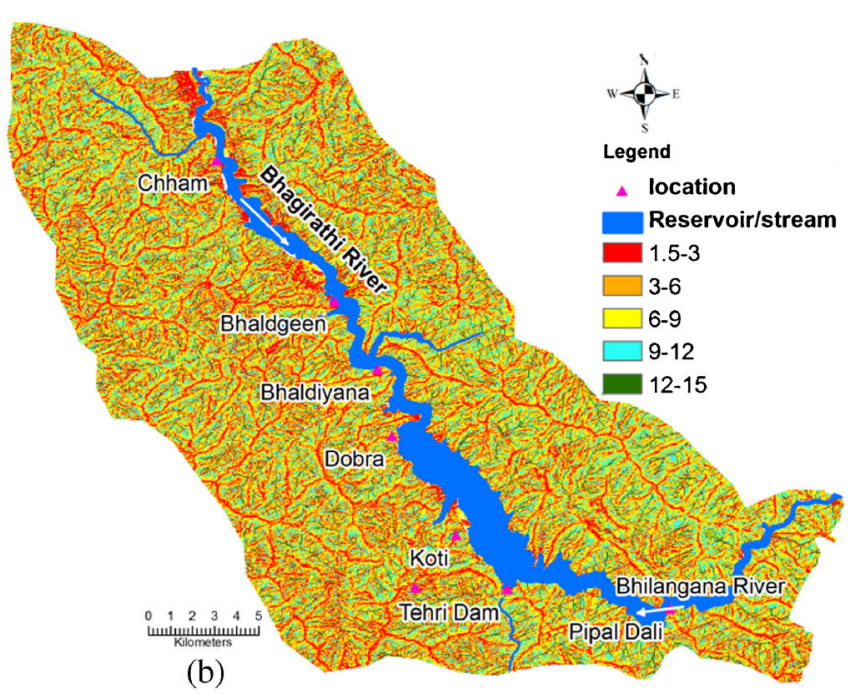

Figure 4. (a) TWI map and (b) SPI map. 


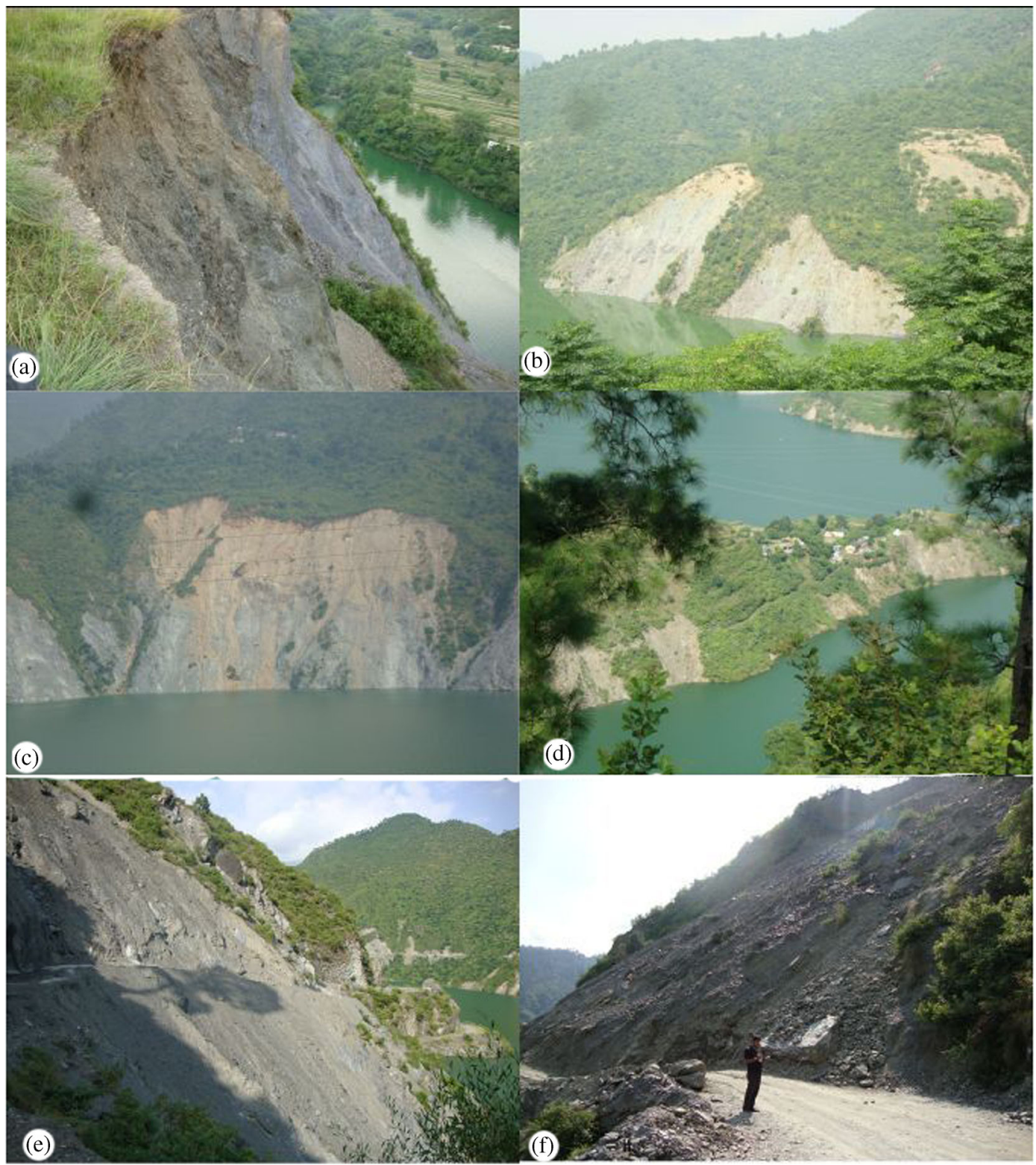

Figure 5. (a, b and $\mathbf{c}$ ) reflects the landslides due to the reservoir induced side slope saturation, (d) refers to the settlements situated (at risk) around the rim of reservoir, (e and $\mathbf{f}$ ) show the consequence of unplanned road construction.

where $A$ is a fuzzy set, $x$ is an element of universal set $R$, and $f(x)$ is the fuzzy membership function. A crisp set range $(0,1)$ has either membership value of 1 or non-membership value of 0 , whereas a fuzzy set inherits continuous membership in the range $(0,1)$. Landslide susceptibility mapping requires determination of fuzzy membership function of causative factors. Fuzzy membership function can be determined subjectively or objectively. There is no universal approach available for the determination of fuzzy membership function. A suitable and universally acceptable approach may enhance information accuracy (prediction capability). For LSZ, several authors have used a knowledge-based approach for assigning fuzzy
Table 3. Different units considered for different fuzzy operation.

\begin{tabular}{lll}
\hline $\begin{array}{l}\text { Units } \\
\text { considered }\end{array}$ & \multicolumn{1}{c}{ Factors } & $\begin{array}{c}\text { Fuzzy } \\
\text { operation }\end{array}$ \\
\hline $\begin{array}{l}\text { Inherent unit } \\
\text { Topographic unit }\end{array}$ & $\begin{array}{l}\text { LULC, soil, geology } \\
\text { Slope, relative relief, } \\
\text { curvature, aspect, }\end{array}$ & $\begin{array}{l}\text { Fuzzy } \gamma \\
\text { Fuzzy OR } \\
\text { TWI, SPI }\end{array}$ \\
& $\begin{array}{l}\text { Drainage buffer, road } \\
\text { buffer, reservoir buffer, } \\
\text { lineament buffer }\end{array}$ & Fuzzy $\gamma$ \\
& & \\
\hline
\end{tabular}

membership function (Chung and Fabbiri 2002; Champatiray et al. 2007). Depending upon the data type (ordered or categorical), a membership 
Table 4. Frequency ration and fuzzy membership values for different attributes.

\begin{tabular}{|c|c|c|c|c|c|}
\hline $\begin{array}{l}\text { Factors and } \\
\text { attributes }\end{array}$ & $\begin{array}{l}\text { Percentage of } \\
\text { domain }\end{array}$ & $\begin{array}{l}\text { No. of } \\
\text { landslides }\end{array}$ & $\begin{array}{c}\text { Percentage of } \\
\text { landslides }\end{array}$ & $\begin{array}{l}\text { Frequency } \\
\text { ratio }\end{array}$ & $\begin{array}{l}\text { Fuzzy member- } \\
\text { ship function }\end{array}$ \\
\hline \multicolumn{6}{|l|}{ Geology } \\
\hline Blaini Formation & 8.69 & 3 & 2.58 & 0.297 & 0.049 \\
\hline Nagthat Formation & 21.8 & 20 & 17.241 & 0.790 & 0.131 \\
\hline Chandpur Formation & 35.47 & 72 & 62.058 & 1.74 & 0.291 \\
\hline Berinag Formation & 13.87 & 11 & 9.48 & 0.683 & 0.113 \\
\hline Deoban Formation & 6.84 & 3 & 2.58 & 0.378 & 0.063 \\
\hline Mandhali Formation & 0.135 & 0 & 0 & 0 & 0 \\
\hline Rautgara Formation & 5.72 & 7 & 5.2 & 0.87 & 0.133 \\
\hline \multicolumn{6}{|l|}{ Soil type } \\
\hline Alluvial/sandy loam & 19.685 & 72 & 62.068 & 3.152 & 0.477 \\
\hline Forest soil/black clay & 47.827 & 6 & 32.758 & 1.008 & 0.152 \\
\hline Sandy loam & 32.486 & 38 & 5.172 & 0.108 & 0.016 \\
\hline \multicolumn{6}{|l|}{ Relative relief } \\
\hline Very low & 4.747 & 0 & 0 & 0 & 0 \\
\hline Low & 28.426 & 3 & 2.586 & 0.09 & 0.013 \\
\hline Moderate & 49.817 & 51 & 43.965 & 0.882 & 0.133 \\
\hline High & 15.256 & 56 & 48.275 & 3.164 & 0.48 \\
\hline Very high & 1.751 & 6 & 5.172 & 2.953 & 0.447 \\
\hline \multicolumn{6}{|l|}{ Slope category } \\
\hline $0^{\circ}-8^{\circ}$ & 13.818 & 0 & 0 & 0 & 0 \\
\hline $8^{\circ}-18^{\circ}$ & 27.442 & 2 & 1.724 & 0.062 & 0.009 \\
\hline $18^{\circ}-30^{\circ}$ & 40.383 & 30 & 25.862 & 0.64 & 0.097 \\
\hline $30^{\circ}-42^{\circ}$ & 17.687 & 82 & 70.689 & 3.996 & 0.605 \\
\hline$>42^{\circ}$ & 0.667 & 2 & 1.724 & 2.581 & 0.391 \\
\hline \multicolumn{6}{|l|}{ Lineament buffer } \\
\hline $0-50 \mathrm{~m}$ & 6.082 & 2 & 1.724 & 0.283 & 0.042 \\
\hline $50-100 \mathrm{~m}$ & 6.532 & 5 & 4.31 & 0.66 & 0.099 \\
\hline $100-150 \mathrm{~m}$ & 13.435 & 11 & 9.482 & 0.705 & 0.106 \\
\hline $150-200 \mathrm{~m}$ & 12.652 & 34 & 29.31 & 2.316 & 0.351 \\
\hline$>200 \mathrm{~m}$ & 61.297 & 64 & 55.172 & 0.9 & 0.136 \\
\hline \multicolumn{6}{|l|}{ Drainage buffer } \\
\hline $0-50 \mathrm{~m}$ & 3.17 & 10 & 8.62 & 2.718 & 0.412 \\
\hline $50-100 \mathrm{~m}$ & 3.217 & 8 & 6.896 & 2.143 & 0.324 \\
\hline $100-150 \mathrm{~m}$ & 6.351 & 12 & 10.344 & 1.628 & 0.246 \\
\hline $150-200 \mathrm{~m}$ & 6.183 & 30 & 25.862 & 4.182 & 0.633 \\
\hline$>200 \mathrm{~m}$ & 81.077 & 56 & 48.275 & 0.595 & 0.09 \\
\hline \multicolumn{6}{|l|}{ LULC type } \\
\hline Dense forest & 5.854 & 0 & 0 & 0 & 0 \\
\hline Scrub forest & 7.476 & 19 & 16.379 & 2.19 & 0.331 \\
\hline Agricultural land & 33.044 & 67 & 57.758 & 1.747 & 0.264 \\
\hline Settlement/fallow land & 24.498 & 30 & 24.137 & 0.985 & 0.149 \\
\hline Water body & 29.126 & 0 & 0 & 0 & 0 \\
\hline \multicolumn{6}{|l|}{ Aspect } \\
\hline North & 14.783 & 14 & 12.068 & 0.816 & 0.123 \\
\hline Northwest & 11.47 & 4 & 3.448 & 0.3 & 0.045 \\
\hline West & 9.593 & 7 & 6.034 & 0.629 & 0.095 \\
\hline Southwest & 12.702 & 14 & 12.068 & 0.95 & 0.143 \\
\hline South & 12.874 & 40 & 34.482 & 2.678 & 0.405 \\
\hline Southeast & 12.771 & 20 & 17.241 & 1.349 & 0.204 \\
\hline East & 10.26 & 10 & 8.62 & 0.84 & 0.127 \\
\hline Northeast & 12.667 & 7 & 6.034 & 0.476 & 0.072 \\
\hline Flat & 2.876 & 0 & 0 & 0 & 0 \\
\hline \multicolumn{6}{|l|}{ TWI } \\
\hline $5-8$ & 61.907 & 39 & 33.62 & 0.543 & 0.082 \\
\hline $8-12$ & 35.035 & 55 & 47.413 & 1.353 & 0.205 \\
\hline $12-16$ & 2.612 & 20 & 17.241 & 6.6 & 1 \\
\hline $16-19$ & 0.444 & 2 & 1.724 & 3.882 & 0.588 \\
\hline
\end{tabular}


Table 4. (Continued.)

\begin{tabular}{|c|c|c|c|c|c|}
\hline $\begin{array}{l}\text { Factors and } \\
\text { attributes }\end{array}$ & $\begin{array}{l}\text { Percentage } \\
\text { of domain }\end{array}$ & $\begin{array}{c}\text { No. of } \\
\text { landslides }\end{array}$ & $\begin{array}{c}\text { Percentage of } \\
\text { landslides }\end{array}$ & $\begin{array}{l}\text { Frequency } \\
\quad \text { ratio }\end{array}$ & $\begin{array}{c}\text { Fuzzy member- } \\
\text { ship function }\end{array}$ \\
\hline \multicolumn{6}{|l|}{ SPI } \\
\hline $1.5-3$ & 67.143 & 47 & 40.517 & 0.603 & 0.091 \\
\hline $3-6$ & 28.043 & 59 & 50.103 & 1.813 & 0.274 \\
\hline $6-9$ & 4.434 & 10 & 8.62 & 1.944 & 0.294 \\
\hline $9-12$ & 0.215 & 0 & 0 & 0 & 0 \\
\hline $12-15$ & 0.163 & 0 & 0 & 0 & 0 \\
\hline \multicolumn{6}{|c|}{ Profile curvature } \\
\hline Concave & 51 & 56 & 48.27 & 0.946 & 0.1433 \\
\hline Convex & 49 & 60 & 51.73 & 1.055 & 0.159 \\
\hline \multicolumn{6}{|c|}{ Road buffer } \\
\hline $0-50 \mathrm{~m}$ & 4.2 & 32 & 27.58 & 6.56 & 1 \\
\hline $50-100 \mathrm{~m}$ & 5 & 24 & 20.68 & 4.136 & 0.62 \\
\hline $100-200 \mathrm{~m}$ & 10.8 & 16 & 13.79 & 1.27 & 0.19 \\
\hline$>200 \mathrm{~m}$ & 80 & 44 & 37.93 & 0.47 & 0.071 \\
\hline \multicolumn{6}{|c|}{ Reservoir buffer } \\
\hline 100 & 3.24 & 30 & 20 & 6.17 & 0.93 \\
\hline 200 & 3.78 & 30 & 20 & 5.29 & 0.80 \\
\hline 300 & 4.47 & 15 & 10 & 2.23 & 0.33 \\
\hline 400 & 5.22 & 5 & 3.3 & 0.63 & 0.095 \\
\hline 500 & 6.14 & 10 & 6.6 & 1.07 & 0.162 \\
\hline$>500$ & 77.15 & 60 & 40 & 0.51 & 0.077 \\
\hline
\end{tabular}

function can be assigned quantitatively by using mathematical formulae. In the present study, 13 categorical layers were considered for fuzzy integration. Mathematical methods of fuzzy membership determination are not fit for categorical data. Landslide factors were compared with landslide inventory and the correlation between them were quantitatively analyzed by landslide frequency ratio method. Landslide frequency ratio can be calculated by ratio of percent domain of a factor class and percent landslide in that class (Lee and Sambath 2006; Poudyal et al. 2010; Pradhan 2010; Pourghasemi et al. 2013). Normalized value of landslide frequency ratio was used as fuzzy membership function by Pradhan et al. (2010). In this study also, frequency ratio results were normalized in the range $(0,1)$. Table 4 depicts frequency ratio and fuzzy membership value of each attribute.

Next step of fuzzy logic technique is fuzzy operation. Fuzzy OR, fuzzy AND, fuzzy algebraic sum, fuzzy algebraic product and fuzzy gamma operator are important fuzzy operators (Chung and Fabbiri 2002). In the case of fuzzy OR and fuzzy AND, only one of the contributing fuzzy set has an effect on resultant value. The fuzzy algebraic sum and fuzzy algebraic product operators make the resultant set larger than or equal to the maximum value and smaller than or equal to the minimum value among all fuzzy sets respectively (Chi et al. 2002). Fuzzy gamma $(\gamma)$ operator calculates values which range between fuzzy algebraic product and fuzzy algebraic sum. $\gamma$ value has a range between 0 (no compensation) and 1 (full compensation). Determination of optimum $\gamma$ value is dependent on the degree of compensation between two extreme confidence levels.

Use of suitable fuzzy operator for the data integration is required to achieve optimum result in landslide prediction studies. Choice of a fuzzy operator depends upon the types of spatial data to be integrated (Choi et al. 2000). All the 13 factors used in the present study were carrying varying degrees of information. Depending upon the character of spatial data, data integration can be carried out by using several different fuzzy operators separately or a combination of operators (Moon 1998). In this study, factors were grouped into following three units: topographic, proximity, and inherent (table 3). Topographic units which included slope, aspect, relative relief, profile curvature, SPI, and TWI were subjected to fuzzy OR operator using the following formula

$$
\begin{aligned}
f_{\mathrm{OR}}\left(x_{t}\right)= & \operatorname{MAX}\left[f_{\text {slope }}(x), f_{\text {aspect }}(x),\right. \\
& f_{\text {relative relief }}(x), f_{\text {profile curvature }}(x), \\
& \left.f_{\text {TWI }}(x), f_{\mathrm{SPI}}(x)\right]
\end{aligned}
$$

Proximity unit included all buffer layers and inherent units included soil, LULC and geology layers. 
Both were subjected to fuzzy $\gamma$ operation using the formula given below

$$
\begin{aligned}
\mathrm{f}_{\gamma}\left(x_{p}\right)= & (\text { Fuzzy Algebraic Sum })^{\gamma} \\
& \times(\text { Fuzzy Algebraic Product })^{1-\gamma} \\
\mathrm{f}_{\gamma}\left(x_{i}\right)=(\text { Fuzzy Algebraic Sum })^{\gamma} & \\
& \left.\times(\text { Fuzzy Algebraic Product })^{1-\gamma}\right)
\end{aligned}
$$

$$
\text { Fuzzy Algebraic Product }=\prod_{i=1}^{n} R_{i}
$$

$$
\text { Fuzzy Algebraic Sum }=1-\prod_{i=1}^{n}\left(1-R_{i}\right)
$$

where $x_{i}, x_{p}$ and $x_{t}$ denote membership functions of inherent, proximity and topographic units
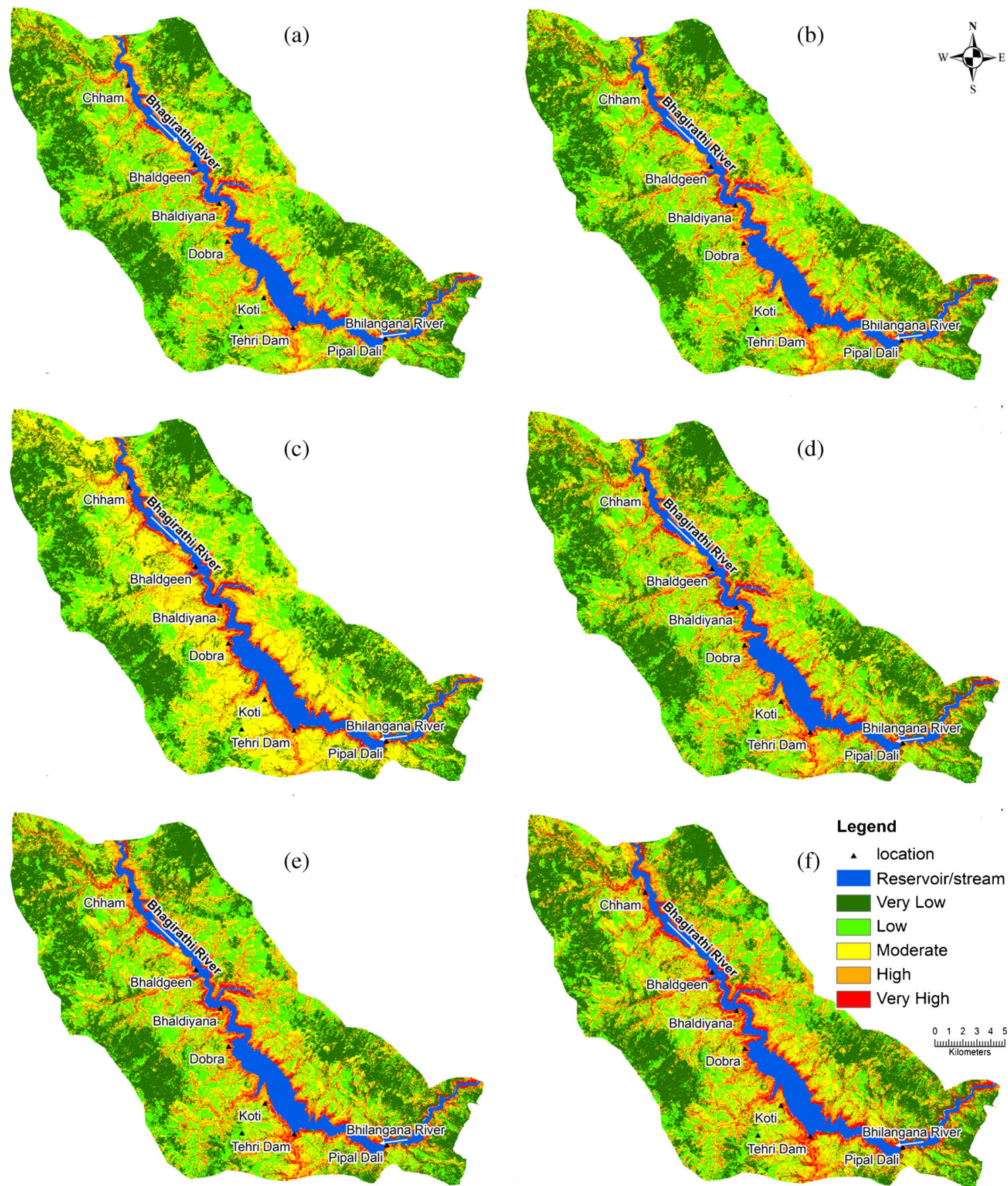

Figure 6. LSZ map of Tehri reservoir rim region based on different fuzzy $\gamma$ operation. (a) $\gamma=0.70$, (b) $\gamma=0.75$, (c) $\gamma=$ $0.80,(\mathbf{d}) \gamma=0.85,(\mathbf{e}) \gamma=0.90$ and $(\mathbf{f}) \gamma=0.95$. 
respectively and also $\left(x_{i}, x_{p}\right.$ and $\left.x_{t}\right) \epsilon x . R_{i}$ denotes fuzzy membership function of $i$ th map, $i=1$, $2, \ldots, n$. Landslide susceptibility index (LSI) map was prepared by subjecting results of equations (4, 5 and 6) to fuzzy gamma operator. Following six $\gamma$ values: $0.7,0.75,0.8,0.85,0.9$, and 0.95 were chosen to prepare six different LSI maps. Another LSI map was prepared by subjecting fuzzy OR operation to the three units considered (table 3). LSI maps are ordered and continuous raster data in which each grid/cell depicts degree of landslide susceptibility quantitatively. Fuzzy operators quantify LSI in a range of $(0,1)$. These LSI maps were categorized into the following five classes: very low, low, moderate, high, and very high susceptibility by applying Jenk's Natural Break (ESRI 2012) classification and accordingly LSZ maps were prepared.

Quantitative prediction accuracy based on cumulative percentage curve and area under curve (AUC) technique was carried out for each landslide susceptibility map. Resulting LSI maps were sliced into 25 equal LSI classes and compared with the landslide data meant for validation. Accordingly, cumulative percentage curves were generated and the value of area under curves (AUC) was calculated using simple trapezium method. AUC was then converted into percent prediction accuracy.

\section{Results and discussion}

\subsection{Landslide frequency ratio}

Landslide frequency ratio was used as fuzzy membership function. Results of frequency ratio have been presented in table 4. Analysis of landslide frequency ratio suggests the importance of landslide causative factors and their classes on landslides. Primary topographic attributes are found to be an important landslide causative factor. Among the slope categories, high landslide frequency ratio is observed in high slope $\left(30^{\circ}-42^{\circ}\right)$ and very high slope category $\left(>42^{\circ}\right)$. High and very high relative relief categories have resulted in high frequency values. Topographic aspect is also found to be an important landslide conditioning factor in the present area. Southern aspect, which receives excessive sun radiation and high rainfall, is more prone to landslides. Very high frequency ratio; 0.9, 2.6 and 1.34 are found for southwest, south and southeast aspect, respectively. Secondary topographic attributes are also found to be important causative factors. High frequency ratio is found in the case of higher ranges $(8-12,12-16,16-19)$ of TWI. In case of SPI, high frequency value is found in 50, 50-100, 100-150, 150-200 and >200 m. Frequency ratio for the range: $0-50,50-100$ and $100-$ $150 \mathrm{~m}$ are found to be high in case of drainage

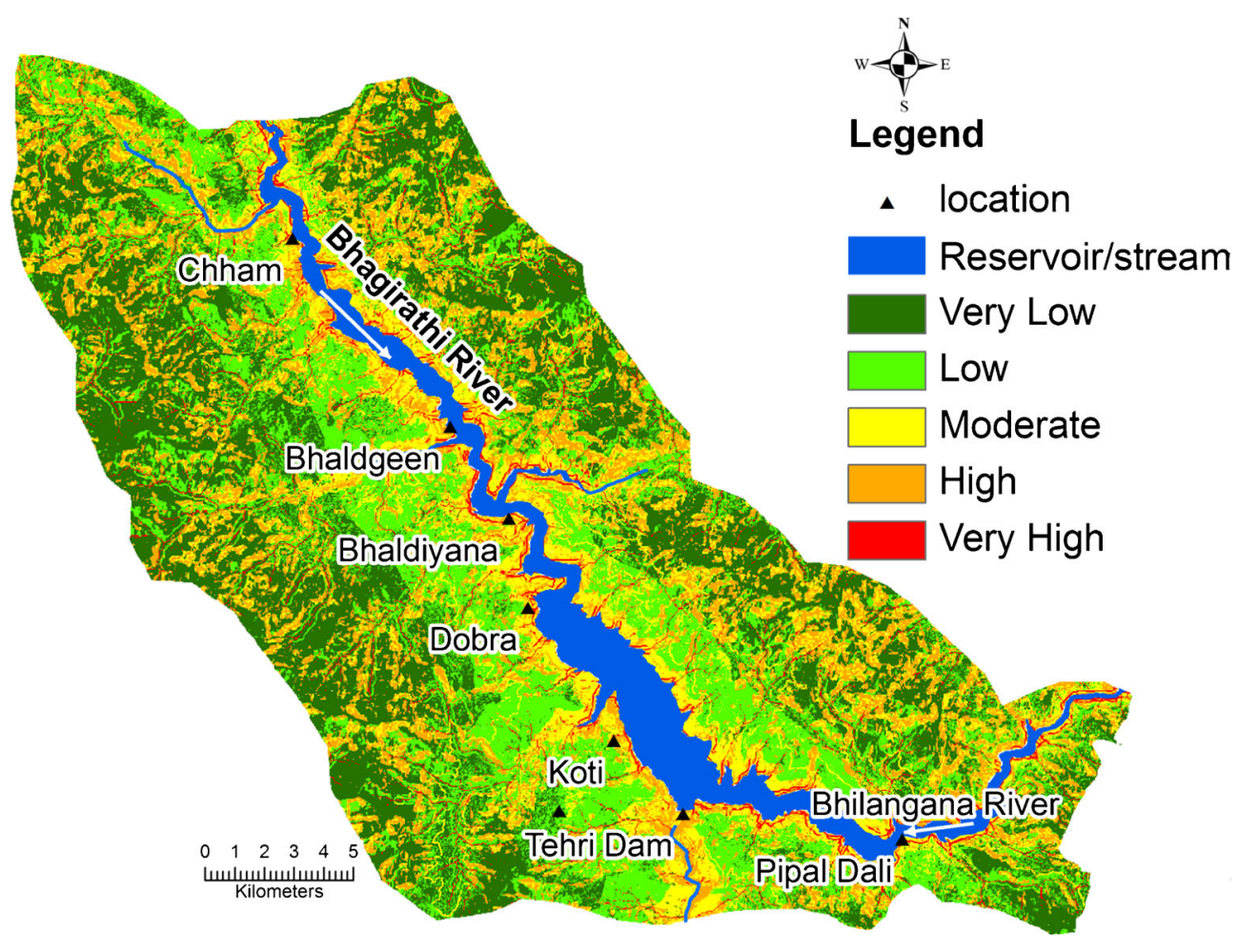

Figure 7. LSZ map of Tehri reservoir rim region based on fuzzy OR operation. 
buffer and lineament buffer classes. Lithology of the area belongs to different formations as mentioned in the previous section. Each formation is represented by characteristic rock type, which might govern landslide incidence. Frequency ratio results of geology layer has reflected that rocks of Chandpur and Nagthat formations are more prone to landslides as they have resulted in high frequency ratio values. Blaini, Mandhali, and Deoban formations constitute slate, quartzite, siltstone, and carbonate rocks, which have resulted in low frequency ratio value. Among the soil categories, alluvial/sandy loam has resulted in high frequency value. Alluvial soil has been observed at lower elevations along the drainage network.

Forest soil and sandy loam has resulted in low frequency ratio values. Reservoir buffer area is mainly formed of different grades of phyllite rocks. Reservoir multi-buffer has reflected progressive decrease of frequency ratio value from $100 \mathrm{~m}$ buffer to $500 \mathrm{~m}$ buffer. Road buffer layers have also shown substantial decrease in frequency ratio value from $0-50 \mathrm{~m}$ buffer to $200 \mathrm{~m}$ buffer. Within

Table 5. LSI range acquired for different fuzzy operations.

\begin{tabular}{lllc}
\hline & Fuzzy operator & Factors involved & Range \\
\hline 1 & Fuzzy $\gamma, \gamma=0.7$ & $\begin{array}{c}\text { Inherent unit, proximity } \\
\text { unit, buffer unit }\end{array}$ & $0-0.789$ \\
2 & Fuzzy $\gamma, \gamma=0.75$ & Same as above & $0-0.821$ \\
3 & Fuzzy $\gamma, \gamma=0.8$ & Same as above & $0-0.854$ \\
4 & Fuzzy $\gamma, \gamma=0.85$ & Same as above & $0-0.888$ \\
5 & Fuzzy $\gamma, \gamma=0.9$ & Same as above & $0-0.924$ \\
6 & Fuzzy $\gamma, \gamma=0.95$ & Same as above & $0-0.961$ \\
7 & Fuzzy OR & Same as above & $0.14-1$ \\
\hline
\end{tabular}

the LULC classes, high landslide frequency value is observed in scrub forest, agricultural land, and settlement/fallow land classes.

\subsection{Landslide susceptibility mapping}

Landslide susceptibility maps were prepared by classifying LSI map. Each cell of LSI map contains susceptibility information in ordered form of range $(0,1)$. A statistical classification based on Jenk's Natural breaks method was used for LSI maps. Natural breaks classes are based on natural clustering inherent in the data. Class breaks are identified that best group similar values and that maximize the differences between classes (ESRI 2012). Six different LSI maps were prepared by applying different gamma operators (figure 6). Fuzzy OR operation was used to integrate inherent, proximity, and buffer units (figure 7). Table 5 depicts the fuzzy operation (including $\gamma$ values), factors considered and resultant LSI range. For different input gamma values different LSI range values were observed. $0-0.789,0-0.821,0-0.854,0-0.888$, 0-0.924, and 0-0.961 range values were observed for $\gamma$ value of $0.70,0.75,0.80,0.85,0.90$, and 0.95 respectively whereas $0.14-1$ range was observed in case of fuzzy OR operation. The range of LSI is strictly an ordered value which represents degree of susceptibility and disregards its (value's) numeric meaning. Natural break classification of LSI maps had resulted threshold values (table 6) based on which very low, low, moderate, high, and very high landslide susceptible zones were acquired. These threshold values indicate ascending tendency of ranges as the $\gamma$ value increases. Fuzzy OR operator has resulted in all nonzero values. Table 7 shows

Table 6. Threshold values of LSZ classes for LSI computed from different fuzzy operation.

\begin{tabular}{|c|c|c|c|c|c|}
\hline $\begin{array}{l}\text { Susceptibility class/ } \\
\text { Fuzzy operator }\end{array}$ & Very low & Low & Moderate & High & Very high \\
\hline Fuzzy $\gamma, \gamma=0.70$ & $0-0.068$ & $0.068-0.186$ & $0.186-0.287$ & $0.287-0.424$ & $0.424-0.789$ \\
\hline$\gamma=0.75$ & $0-0.084$ & $0.084-0.218$ & $0.218-0.322$ & $0.322-0.457$ & $0.457-0.821$ \\
\hline$\gamma=0.80$ & 0 & $0-0.271$ & $0.271-0.395$ & $0.395-0.542$ & $0.542-0.854$ \\
\hline$\gamma=0.85$ & 0 & $0-0.313$ & $0.313-0.428$ & $0.428-0.571$ & $0.571-0.888$ \\
\hline$\gamma=0.90$ & 0 & $0-0.376$ & $0.376-0.500$ & $0.500-0.641$ & $0.641-0.924$ \\
\hline$\gamma=0.95$ & 0 & $0-0.437$ & $0.437-0.565$ & $0.565-0.712$ & $0.712-0.961$ \\
\hline Fuzzy OR & $0.14-0.21$ & $0.21-0.33$ & $0.33-0.46$ & $0.46-0.62$ & $0.62-1$ \\
\hline
\end{tabular}

Table 7. Area frequency of LSZ classes resulted from different fuzzy operation.

\begin{tabular}{lclcrrrr}
\hline Fuzzy operator/LSZ & Fuzzy OR & $\gamma=0.70$ & $\gamma=0.75$ & $\gamma=0.80$ & $\gamma=0.85$ & $\gamma=0.90$ & $\gamma=0.95$ \\
\hline Very low & 179.51 & 173 & 172.87 & 172.82 & 172.82 & 172.82 \\
Low & 141.36 & 154.63 & 148.349 & 87.20 & 137.19 & 130.68 \\
Moderate & 96.48 & 129.77 & 122.035 & 160.55 & 116.87 & 116.22 \\
High & 112.30 & 69.85 & 77.723 & 79.58 & 89.99 & 93.77 & 104.50 \\
Very high & 19.59 & 22 & 28.28 & 49.08 & 32.37 & 35.75 \\
\hline
\end{tabular}


area under susceptible classes observed for various fuzzy operations.

\section{Validation of landslide susceptibility mapping}

Validation was performed to obtain the accuracy of landslide susceptibility zones. Accuracy of LSZ is the capability of the map to delineate landslide free and landslide prone areas. Comparison of different models and model parameter variables can also be done from validation (Begueria 2006). Accuracy and objectivity depend on the model accuracy, input data, experience of earth scientist, and size of the study area (Soeters and Van Westen 1996). In the present study, cumulative percentage curve/success rate curve technique was used to validate susceptible zones. Cumulative percentage curves were achieved by plotting cumulative percent of LSI in descending order against cumulative percent of landslide on $\mathrm{X}$ and $\mathrm{Y}$ axis respectively. Example of the curve is given in figure 8 . Figure 8 indicates that $58 \%$ of the landslide falls

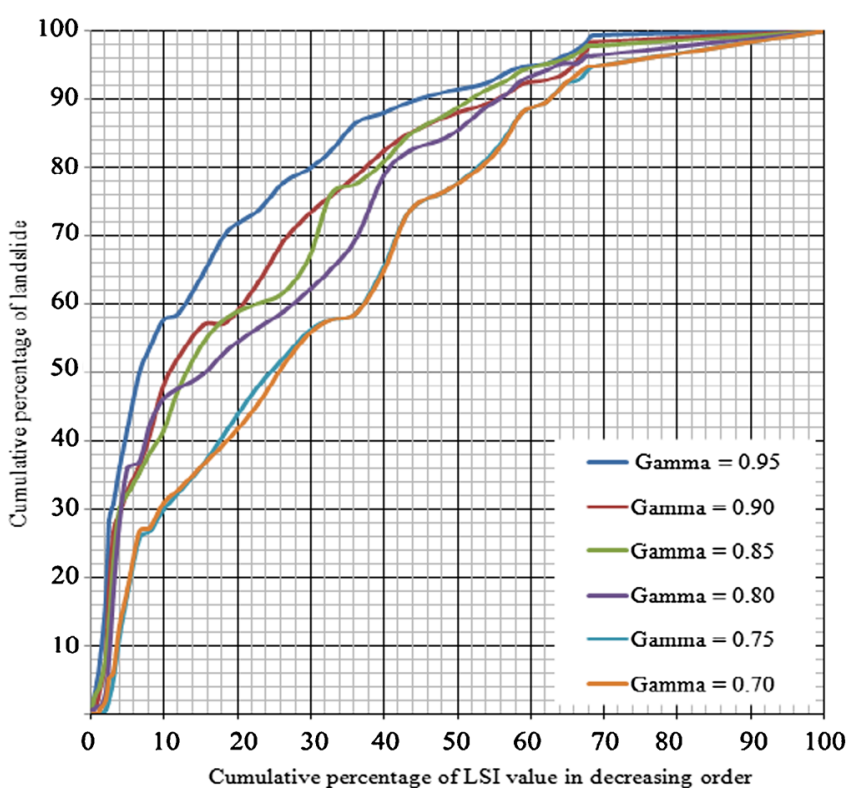

Figure 8. Cumulative percentage curve of LSI computed from fuzzy OR operator.

Table 8. AUC values with respect to gamma $(\gamma)$ values.

\begin{tabular}{lll}
\hline Gamma $(\gamma)$ & $\begin{array}{c}\text { AUC } \\
\text { values }\end{array}$ & \% Accuracy \\
\hline 0.95 & 0.834 & 83.45 \\
0.90 & 0.821 & $82.1 \%$ \\
0.85 & 0.818 & $81.8 \%$ \\
0.80 & 0.80 & $80 \%$ \\
0.75 & 0.796 & $79.6 \%$ \\
0.70 & 0.778 & $77.8 \%$ \\
Fuzzy OR & 0.74 & $74 \%$ \\
\hline
\end{tabular}

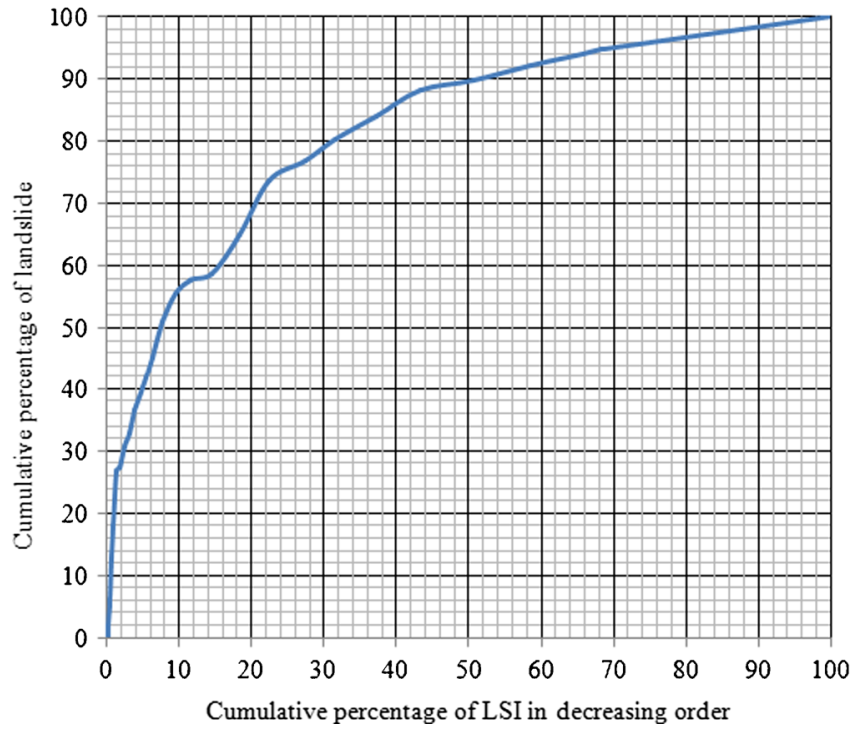

Figure 9. Cumulative percentage curves referring to comparison between LSI acquired by various gamma values.

under $10-90 \%$ of high susceptible classes whereas $12 \%$ landslide falls under $90-80 \%$ susceptible class, and accordingly other values follow. In this way, percentage cumulative curve clearly states the accuracy of the LSZ. Further, AUC value of accuracy curves were calculated by simple trapezium method. AUC value of $0.834,0.821,0.818,0.80$, 0.796 and 0.778 were achieved for $\gamma$ value of 0.95 , $0.9,0.85,0.80,0.75$, and 0.70 , respectively, whereas fuzzy OR operator resulted in AUC value of 0.74 (table 8). Henceforth, it can be said in percentage terms that $83.4 \%$ accuracy has been achieved for $\gamma$ value of 0.95 and so on. Higher $\gamma$ values have resulted in better accuracy, whereas fuzzy OR operator has given least accuracy. Figure 9 refers to comparison between results of different $\gamma$ values used in this study.

\section{Conclusions}

Fuzzy logic relations and fuzzy operation based landslide susceptibility zonation have achieved satisfying results. Fuzzy membership values were determined by frequency ratio approach. Frequency ratio of each factor's attributes was determined. High frequency ratio values were observed for primary topographic attributes. Slope and relative relief were found to be major landslide causative factors in Tehri reservoir rim area. Within secondary topographic attributes, TWI shows high frequency ratio results. Frequency ratio results of SPI show substantial correlation with landslide frequency in the present area. This study shows that secondary topographic units play an important role in landslide occurrences in the study area. To perform fuzzy operation for 13 factors, 
which contain varying degrees of spatial information, factors were grouped into inherent, topographic and proximity units. Fuzzy $\gamma$ and fuzzy OR operators were used to separately integrate factors present in these units as mentioned in section 3 . Later these integrated units were subjected to fuzzy $\gamma$ and fuzzy OR operation separately. Combined approach of fuzzy operation has enhanced the prediction accuracy. Fuzzy gamma operators were successfully applied for the generation of LSI maps and consequent LSZ. The model suggests that higher gamma values $(0.95,0.90)$ yield better prediction of landslide susceptibility than low gamma values (0.8. 0.75 and 0.70), whereas fuzzy OR had given least accuracy. Results show increasing tendency of susceptibility prediction corresponding to increasing gamma values. Model accuracy was performed using cumulative percentage curves. Resulting smooth curves suggest good prediction results, whereas AUC values of curves also indicate better prediction. Gamma value of 0.95 was chosen for the final landslide susceptibility map generation. Hence it can be concluded that landslide causative factor's integration using fuzzy logic has yielded good results for Tehri reservoir rim region. Frequency ratio method for determination of fuzzy membership value has reduced subjectivity in the model. It is also concluded that cumulative percentage curves method has a strong validation capability for a continuous susceptibility model.

\section{References}

AHEC report for Uttarakhand government 2008 Impact of Tehri dam lessons learnt; www.iitr.ernet.in/centers/ AHEC/pages/index.html.

Akgun A, Dag S and Bulut F 2008 Landslide susceptibility mapping for a landslide-prone area (Findikli, NE of Turkey) by likelihood-frequency ratio and weighted linear combination models; Environ. Geol. 54 1127-1143.

Anbalagan R 1992 Landslide hazard evaluation and zonation mapping in mountainous terrain; Eng. Geol. 32 269-277.

Anbalagan R, Chakraborty D and Kohli A 2008 Landslide hazard zonation (LHZ) mapping on meso-scale for systematic town planning in mountainous terrain; J. Sci. Indus. Res. 67 486-497.

Arora M K, Das Gupta A S and Gupta R P 2004 An artificial neural network approach for landslide hazard zonation in the Bhagirathi (Ganga) Valley, Himalayas; Int. J. Rem. Sens. 25 559-572.

Ayalew L and Yamagishi H 2005 The application of GIS based logistic regression for landslide susceptibility mapping in the Kakuda-Yahiko Mountains, central Japan; Geomorphology 65(1/2) 15-31.

Begueria S 2006 Validation and evaluation of predictive models in hazard assessment and risk management; Nat. Hazards 37 315-329.

Brabb E E 1984 Innovative approaches to landslide hazard mapping; In: Proceedings 4th International Symposium on Landslides, Toronto 1 307-324.

Carrara A, Cardinali M, Guzzeti F and Reichenbach P 1995 GIS technology in mapping landslide hazard; In:
Geographical Information Systems in Assessing Natural hazards (eds) Carrara A and Guzzetti F (Dordrecht, The Netherlands: Kluwer Academic Publishers), pp. 135-175.

Chakraborty D and Anbalagan R 2008 Landslide hazard evaluation of road cut slopes along Uttarkashi-Bhatwari road, Uttaranchal Himalaya; J. Geol. Soc. India 71 $115-124$.

Champatiray P K, Dimri S, Lakhera R C and Sati S 2007 Fuzzy-based method for landslide hazard assessment in active seismic zone of Himalaya; Landslides 4 101111.

Chauhan S, Mukta Sharma, Arora M K and Gupta N K 2010 Landslide susceptibility zonation through ratings derived from Artificial Neural Network; Int. J. Appl. Earth Observ. Geoinf. 12 340-350.

Chi K H, Park N W and Lee K 2002 Identification of landslide area using Remote Sensing Data and quantitative assessment of landslide hazard; Proc. IEEE Int. Geosci. Rem. Sens. Symp., 19 July Toronto, Canada.

Choi S W, Moon W M and S G 2000 Fuzzy logic fusion of W-Mo exploration data from Seobyeog-ri, Korea; Geosci. J. 4(2) 43-52.

Chung C F and Fabbiri A G 2002 Prediction models for landslide hazard zonation using a fuzzy set approach; In: Geomorphology \&6 Environmental Impact Assesment (eds) Marchetti M and Rivas V, Balkema Publishers, pp. 31-47.

Clerici A, Perego S, Tellini C and Vescovi P 2002 A procedure for landslide susceptibility zonation by the conditional analysis method; Geomorphology 48 349-364.

Dahal R K, Hasegawa S, Nonomura S, Yamanaka M, Masuda T and Nishino K 2008 GIS-based weights-ofevidence modelling of rainfall-induced landslides in small catchments for landslide susceptibility mapping; Environ. Geol. 54(2) 314-324.

Das I, Sahoo S, Van Westen C J, Stein A and Hack R 2010 Landslide susceptibility assessment using logistic regression and its comparison with a rock mass classification system, along a road section in the northern Himalayas (India); Geomorphology 114 627-637.

Das I, Stein A, Kerle N and Dadhwal 2012 Landslide susceptibility mapping along road corridors in the Indian Himalayas using Bayesian logistic regression models; Geomorphology 179 116-125.

Ercanoglu M and Gokceoglu C 2002 Assessment of landslide susceptibility for a landslide-prone area (north of Yenice, NW Turkey) by fuzzy approach; Environ. Geol. 41 720-730.

Ercanoglu M and Gokceoglu C 2004 Use of fuzzy relations to produce landslide susceptibility map of a landslide prone area (West Black Sea Region, Turkey); Eng. Geol. 75(34) $229-250$.

Ercanoglu M, Kasmer O and Temiz N 2008 Adaptation and comparison of expert opinion to analytical hierarchy process for landslide susceptibility mapping; Bull. Eng. Geol. Environ. 67 565-578.

ESRI FAQ 2012 What is the Jenks optimization method? http://support.esri.com/en/knowledgebase/techarticles/ detail/26442.

Ghosh S, Van Westen C J, Carranza E J M, Ghoshal T B, Sarkar N K and Surendranath M 2009 A quantitative approach for improving the BIS (Indian) method of medium-scale landslide susceptibility; J. Geol. Soc. India 74(5) 625-638.

Ghosh S, Carranza E J M, van Westen C J, Jetten V G and Bhattacharya D N 2011 Selecting and weighting of spatial predictors for empirical modeling of landslide susceptibility in Darjeeling Himalaya (India); Geomorphology 131 $35-56$. 
Gupta R P, Saha A K, Arora M K and Kumar A 1999 Landslide hazard zonation in a part of the Bhagirathi Valley Garhwal Himalayas using integrated remote sensing-GIS; Him. Geol. 20 71-85.

Guzzetti F, Carrara A, Cardinali M and Reichenbach P 1999 Landslide hazard evaluation: A review of current techniques and their application in a multi-scale study, central Italy; Geomorphology 31 181-216.

Guzzetti F, Reichenbach P, Cardinali M, Galli M and Ardizzone F 2005 Probabilistic landslide hazard assessment at the basin scale; Geomorphology 72 272-299.

Hasekiogullari G D and Ercanoglu M 2012 A new approach to use AHP in landslide susceptibility mapping: A case study at Yenice (Karabuk, NW Turkey); Nat. Hazards 63 1157-1179, doi: 10.1007/s11069-012-0218-1.

Hutchinson J N 1995 Landslide hazard assessment; In: Proc. VI Int. Symp. on Landslides Christchurch 1 1805-1842.

Kanungo D P, Arora M K, Sarkar S and Gupta R P 2006 A comparative study of conventional, ANN black box, fuzzy and combined neural and fuzzy weighting procedures for landslide susceptibility zonation in Darjeeling Himalayas; Eng. Geol. 85 347-366.

Kanungo D P, Arora M K, Sarkar S and Gupta R P 2009a Landslide susceptibility zonation (LSZ) mapping - A review; J. South Asia Dis. Stu. 2 81-105.

Kanungo D P, Arora M K, Sarkar S and Gupta R P 2009b A fuzzy set based approach for integration of thematic maps for landslide susceptibility zonation; Georisk Assess. Manage. Risk Eng. Syst. Geohazards 3(1) 30-43.

Kayastha P, Dhital M R and De Smedt F 2012 Landslide susceptibility mapping using weight of evidence in the Tinau watershed, Nepal; Nat. Hazards 63(2) 479-498.

Kayastha P, Dhital M and De Smedt F 2013a Application of the analytical hierarchy process (AHP) for landslide susceptibility mapping: A case study from the Tinau Watershed, west Nepal; Comput. Geosci. 52 398-408.

Kayastha P, Bijukchhen S M, Dhital M and De Smedt F 2013b GIS based landslide susceptibility mapping using a fuzzy logic approach: A case study from Ghurmi-Dhad Khola area, eastern Nepal; J. Geol. Soc. India $\mathbf{8 2}$ 249-261.

Kumar R and Anbalagan R 2013 Pixel based terrain analysis for landslide hazard zonation, a case study of Tehri reservoir region, Uttarakhand, India; In: Geosci. Rem. Sens. Symp. (IGARSS), IEEE, Int., pp. 2868-2871.

Kundu S, Saha A K, Sharma D C and Pant C C 2013 Remote Sensing and GIS based landslide susceptibility assessment using binary logistic regression model: A case study in the Ganeshganga Watershed, Himalayas; J. Indian Soc. Rem. Sens. 41(3) 697-709.

Lee S 2005 Application of logistic regression model and its validation for landslide susceptibility mapping using GIS and remote sensing data; Int. J. Rem Sens. 26(7) 14771491.

Lee S and Sambath T 2006 Landslide susceptibility mapping in the Damrei Romel area, Cambodia using frequency ratio and logistic regression models; Environ. Geol. 50 847-855.

Lee S, Choi J and Min K 2002 Landslide susceptibility analysis and verification using the Bayesian probability model; Environ. Geol. 43 120-131.

Mathew J, Jha V K and Rawat G S 2007 Weights of evidence modelling for landslide hazard zonation mapping in part of Bhagirathi valley, Uttarakhand; Curr. Sci.92(5) $628-638$.

Mathew J, Jha V K and Rawat G S 2009 Landslide susceptibility zonation mapping and its validation in part of Garhwal Lesser Himalaya, India, using Binary Logistic
Regression analysis and receiver operating characteristic curve method; Landslides 6 17-26.

Mondal S and Maiti R 2012 Landslide susceptibility analysis of Shiv-Khola Watershed, Darjiling: A remote sensing and GIS based Analytical Hierarchy Process (AHP); J. Indian Soc. Rem. Sens. 40(3) 483-496.

Moon W M 1998 Integration and fusion of geological exploration data: A theoretical review of fuzzy logic approach; Geosci. J. 2(4) 175-183.

Nagarajan R, Mukherjee A, Roy A and Khire M V 1998 Temporal remote sensing data and GIS application in landslide hazard zonation of part of Western Ghat, India; Int. J. Rem. Sens. 19(4) 573-585.

Pachauri A K and Pant M 1992 Landslide hazard mapping based on geological attributes; Eng. Geol. 32(1-2) 81-100.

Poudyal C P, Chang C, Oh H and Lee S 2010 Landslide susceptibility maps comparing frequency ratio and artificial neural networks: A case study from the Nepal Himalaya; Environ. Earth Sci. 61 1049-1064.

Pourghasemi H R, Goli Jirandeh A, Pradhan B, Xu C and Gokceoglu C 2013 Landslide susceptibility mapping using support vector machine and GIS; J. Earth Syst. Sci. 122(2) 349-369.

Pradhan B 2010 Application of an advanced fuzzy logic model for landslide susceptibility analysis; Int. J. Comput. Intel. Sys. 3(3) 370-381.

Pradhan B and Lee S 2010 Delineation of landslide hazard areas on Penang Island, Malaysia, by using frequency ratio, logistic regression, and artificial neural network models; Environ. Earth Sci. 60 1037-1054.

Pradhan B, Lee S and Buchroithner M F 2009 Use of geospatial data and fuzzy algebraic operators to landslidehazard mapping; Applied Geomatics $13-15$.

Pradhan B, Lee S and Buchroithner M 2010 Remote sensing and GIS-based landslide susceptibility analysis and its cross-validation in three test areas using a frequency ratio model; Photogram. Fernerkundung GeoInf. 1 17-32.

Saha A K, Gupta R P and Arora M K 2002 GIS-based landslide hazard zonation in a part of the Himalayas; Int. J. Rem. Sens. 23(2) 357-369.

Saha A K, Gupta R P, Sarkar I, Arora M K and Csaplovics E 2005 An approach for GIS-based statistical landslide susceptibility zonation with a case study in the Himalayas; Landslides 2 61-69.

Sarkar S and Kanungo D P 2004 An integrated approach for landslide susceptibility mapping using remote sensing and GIS; Photogram. Eng. Rem. Sens. 70(5) 617625.

Sarkar S, Kanungo D P, Kumar P and Patra A K 2008 GIS based spatial data analysis for landslide susceptibility mapping; J. Math. Sci. 5 52-62.

Sharma S, Raghuvanshi T and Anbalagan R 1994 Plane failure analysis of rock slopes; Geotec. Geol. Eng. Int. J. 13 105-111.

Singh T N, Gulati A, Dontha L K and Bharadwaj V 2008 Evaluating cut slope failure by numerical analysis - a case study; Nat. Hazards 47 263-279.

Soeters R and Van Westen C J 1996 Slope stability: Recognition, analysis and zonation; In: Landslides: investigation and mitigation (eds) Turner A and Shuster R (Washington D C: National Academy Press), pp. 129-177.

Valdiya K S 1980 Geology of Kumaun Lesser Himalaya; Dehradun: Wadia Institute of Himalayan Geology; Interim Report 291.

Van Westen C J, Rengers N and Soeters R 2003 Use of geomorphological information in indirect landslide 
susceptibility assessment; Nat. Hazards $30 \quad 399-$ 419.

Van Westen C J, Van Asch T W J and Soeters R 2006 Landslide hazard and risk zonation - why is it still so difficult? Bull. Eng. Geol. Environ. 65 167-184.

Varnes D J 1984 International Association of Engineering Geology Commission on Landslides and Other Mass Movements on Slopes: Landslide Hazard Zonation: A Review of Principles and Practice; Paris: UNESCO, $63 \mathrm{p}$.

Watershed Management Directorate, Dehradun 2009 Report on Uttarakhand State perspective and strategic planning 2009-2027, file://D:/For\%20review/UTTAR AKHAND\%20SOIL.pdf.
Wilson J 2011 Digital terrain modelling; Geomorphology 5 269-297.

Yalcin A 2008 GIS-based landslide susceptibility mapping using analytical hierarchy process and bivariate statistics in Ardesen (Turkey): Comparisons of results and confirmations; Catena 72 1-12.

Yilmaz I 2009 Landslide susceptibility mapping using frequency ratio, logistic regression, artificial neural networks and their comparison: A case study from Kat landslides (Tokat, Turkey); Comput. Geosci. 35(6) 1125-1138.

Zadeh L A 1965 Fuzzy sets; Inf. Control 8 253-338.

Zimmermann H J 1996 Fuzzy set theory and its applications; Kluwer Academic Publishers, 435p.

MS received 20 March 2014; revised 5 August 2014; accepted 20 September 2014 